\title{
Virus phenotype variability during disease progression of HIV-I infected children
}

\author{
Mariangela Cavarelli*1, Stefania Dispinseri ${ }^{1}$, Chiara Ripamonti ${ }^{1}$, \\ Ingrid Karlsson ${ }^{2}$, Liselotte Antonsson ${ }^{3}$, Anna Plebani ${ }^{4}$, Eva-Maria Fenyö ${ }^{2}$ and \\ Gabriella Scarlatti ${ }^{1}$
}

Address: ${ }^{1}$ Viral Evolution and Transmission Unit, DIBIT, HSR, Milan 20132, Italy, ${ }^{2}$ Division of Medical Microbiology/Virology, Department of Laboratory Medicine, Lund University, Lund, Sweden, ${ }^{3}$ Division of Cellular and Molecular Pharmacology, Department of Experimental Medical Science, Lund University, Lund 223 62, Sweden and ${ }^{4}$ Department of Pediatrics, University of Milan, Clinica de Marchi, Milan 20122, Italy

* Corresponding author

from Fourth Dominique Dormont International Conference. Host-Pathogen Interactions in Chronic Infections Paris, France. 13-15 December 2007

Published: 9 April 2008

Retrovirology 2008, 5(Suppl I):O28 doi:I0.II86/I742-4690-5-SI-O28

This abstract is available from: http://www.retrovirology.com/content/5/SI/O28

(c) 2008 Cavarelli et al.; licensee BioMed Central Ltd.

\section{Background}

HIV-1 infected children display different clinical evolution, i.e., "fast progression" (FP), "slow progression" (SP) and "long term non progression" (LTNP). One important phenotypic trait linked to disease progression is the evolution of the viral co-receptor use [1], involving a change from CCR5 to CXCR4 use [2]. However, AIDS symptoms can appear in absence of X4 viruses. Recently chimeric receptors between CCR5 and CXCR4 were developed, in which subsequent parts of CCR5 were replaced with corresponding parts of CXCR4 [3]. Their use allowed to document the biological variability of R5 isolates during the pathogenic process in adults [4].

\section{Aim}

To examine the HIV biological variability in children with different modes of disease progression.

\section{Materials and methods}

119 isolates from 19 HIV-1 positive children were tested for their ability to infect U87.CD4+ cells expressing the wild type receptor CCR5, CXCR4, or one of the 6 chimeric CCR5/CXCR4 receptors.

\section{Results}

Early during infection, all the viruses isolated from 8 SP children used only wild type CCR5 (called R5narrow). In one case, this phenotype persisted during disease progression, whereas in 2 children the virus evolved and was able to use multiple chimeric receptors (called R5 ${ }^{\text {broad }}$ ), and in additional 5 children the virus evolved to CXCR4 usage. Interestengly the FP children, carried close to birth in 2 cases $\mathrm{R} 5^{\text {narrow }}$ virus, in 2 cases $\mathrm{R} 5^{\text {broad }}$ and in one case a dualtropic R5X4 virus. Virus with R5narrow evolved to R5 broad in one of the 2 children carrying such phenotype. Both children with R5broad phenotype developed CXCR4 variants during the follow-up.

Evolution was observed also in the LTNP, although followed from later on in life ( $>8$ years of age): all tested isolates from $2 / 6$ LTNP remained R5 narrow during disease progression; in one child an evolution from R5 $5^{\text {narrow }}$ to R5 $5^{\text {broad }}$ was observed whereas in another child the virus evolved from R5narrow to R5X4. The remaining two children showed R5 $5^{\text {broad }}$ phenotype during the whole followup.

\section{Conclusions}

Our results show that HIV-1 with broad chimeric receptor use is not hampered in transmission, and is more frequent close to birth in FP than in SP children. Viruses from LTNP show a similar phenotypic evolution though at later age. 


\section{References}

I. Bjorndal A, Deng H, Jansson M, Fiore JR, Colognesi C, Karlsson A, Albert J, Scarlatti G, Littman DR, Fenyo EM: Coreceptor usage of primary human immunodeficiency virus type $I$ isolates varies according to biological phenotype. J Virol. 1997, 71:7478-7487.

2. Karlsson I, Antonsson L, Shi Y, Karlsson A, Albert J, Leitner T, Olde $B$, Owman C, Fenyo EM: HIV biological variability unveiled: frequent isolations and chimeric receptors reveal unprecedented variation of coreceptor use. AIDS 2003, 17:256|-2569.

3. Antonsson L, Boketoft A, Garzino-Demo A, Olde B, Owman C: Molecular mapping of epitopes for interaction of HIV-I as well as natural ligands with the chemokine receptors, CCR5 and CXCR4. Aids 2003, I 7:257I-2579.

4. Karlsson I, Antonsson L, Shi Y, Oberg M, Karlsson A, Albert J, Olde $B$, Owman C, Jansson M, Fenyö EM: Coevolution of RANTES sensitivity and mode of CCR5 receptor use by human immunodeficiency virus type I of the R5 phenotype. J Virol 2004, 78: $|1807-1| 8 \mid 5$.

Publish with Bio Med Central and every scientist can read your work free of charge

"BioMed Central will be the most significant development for disseminating the results of biomedical research in our lifetime. "

Sir Paul Nurse, Cancer Research UK

Your research papers will be:

- available free of charge to the entire biomedical community

- peer reviewed and published immediately upon acceptance

- cited in PubMed and archived on PubMed Central

- yours - you keep the copyright

Submit your manuscript here:

http://www.biomedcentral.com/info/publishing_adv.asp 